\title{
Development of a territorial tourism product using a marketing and analytical approach
}

\author{
Natalia Lukyanova ${ }^{* 1}$, and Aleksandr Stremousov ${ }^{2}$ \\ ${ }^{1}$ Immanuel Kant Baltic Federal University, 14 Alexander Nevsky str., 236041 Kaliningrad, Russia \\ ${ }^{2}$ Higher School of Economics National Research University, 20 Myasnitskaya str., 101000 Moscow, \\ Russia
}

\begin{abstract}
The article describes the author's method of forming the concept of a territorial tourist product within the framework of a marketing and analytical approach. The methodology is based on marketing research, the use of statistical analysis to objectively substantiate the proposed investment decisions in the field of tourism infrastructure and the management of strategic development of the territories, as well as on the construction of a marketing multi-attribute model of a territorial tourism product. The proposed methodology is implemented in the municipal unit of the Kaliningrad region within the framework of the investment "Strategy for the socio-economic development of "Ladushkinsky urban district" municipal unit for 2020-2030". The article presents the results of marketing and analytical research, on the basis of which the concept of the territorial tourist product of the Ladushkinsky urban district was developed, which implements its portfolio of the investment projects, as well as its marketing complex according to the "4P" model.
\end{abstract}

\section{Introduction}

In accordance with the provisions of the "Strategy for the Economic Security of the Russian Federation for the Period up to 2030" one of the modern threats to the development of the Russian economy is the uneven spatial development of the Russian Federation and the increasing differentiation of regions and municipalities in terms of the level and pace of socio-economic development [1]. The importance of this problem has been repeatedly emphasized by domestic economists, who, in particular, do not see an opportunity to overcome the differentiation of regions in the near future [3].

Regional managers are in constant search of the reserves and drivers of the territorial development. One of such effective options for the socio-economic development of regions and municipalities is tourism, since it is one of the most powerful mechanisms for increasing the competitiveness of the economy and is a source of financial revenues for the budget at all levels [3].

The Kaliningrad region is an exclave territory of Russia, attractive for both domestic and international tourism. Amid the COVID-19 pandemic, the region was visited by a record number of tourists ever during the summer season of 2020. However, the region has

\footnotetext{
* Corresponding author: nlukyanova@kantiana.ru
} 
successfully coped with such an influx of guests and is ready to expand its tourism opportunities.

At the same time, one of the most significant problems that hinder the successful development of the tourist and recreational potential of the region and the North-West of Russia as a whole is the underdevelopment of the tourist and recreational infrastructure and its unbalanced development in individual components [4]. So, in the Kaliningrad region, indeed, there is a fairly strong differentiation of municipalities in terms of tourism and recreation development. For example, one of the most promising municipalities of the Kaliningrad region, from the point of view of the potential of recreational and tourist development, is "City of Ladushkin" urban district municipal unit. However, the level of its recreational and tourist infrastructure and supply in the local sectoral market is extremely low [5].

Taking into account the above, the authors of the article, as part of the development of an investment strategy for the socio-economic development of the Ladushkinsky urban district, carried out a scientific research on the development of a territorial tourist product, including the development of a concept and an agreed portfolio of the investment projects for the development of the territory.

\section{Methods for the development of a territorial tourism product using a marketing and analytical approach}

As a number of scientific studies show, one of the main factors constraining the development of tourism is the low competitiveness of the tourist product and its low tourist attractiveness. Taking this into account, the authors of the study used a marketing and analytical approach based on taking into account the interaction of the forces of supply and demand, on the results of relevant marketing research, and also taking into account the needs and preferences of tourists [6-8], which thereby contributes to:

- more flexible response of the proposal to the objectively researched conjuncture of the tourist services market;

- development of a new tourism product or development of a new market niche with a high level of competitiveness in the local, national and international markets;

- ensuring the sustainable development of the territorial tourism activities.

The methodology for the development of a territorial tourism product, developed by the authors of the article on the basis of a marketing and analytical approach, is shown in Figure 1. Taking into account the results of the SWOT analysis of the territory, the authors formed a marketing multi-attributive model of the territorial tourism product (Fig. 2). 


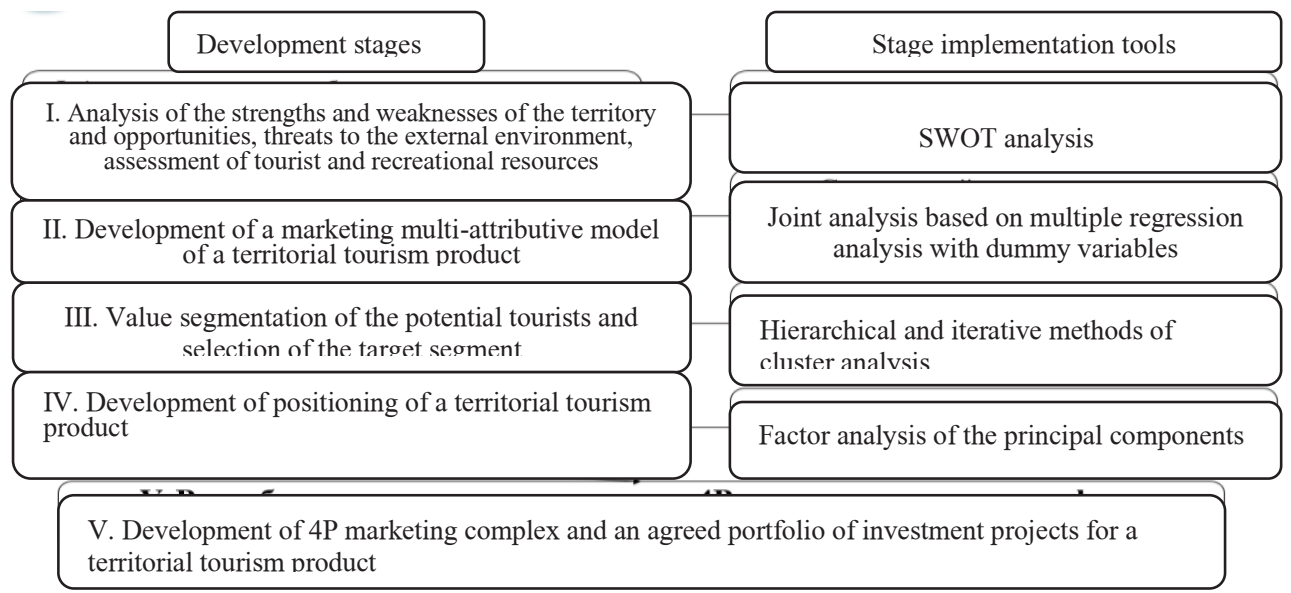

Fig. 1. Technology for the development of a territorial tourist product based on a marketing and analytical approach

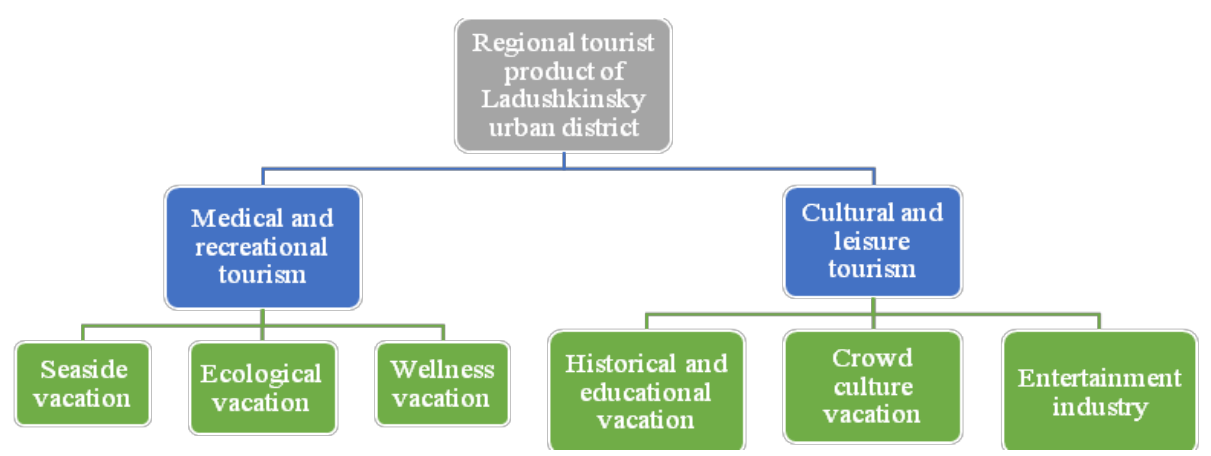

Fig. 2.Marketing multi-attributive model of the territorial tourist product of the Ladushkinsky urban district

This model was formalized in accordance with the requirements of the regression analysis in the form of a model with dummy variables (Table 1).

Table 1. Formalization of the marketing model in accordance with the requirements of the regression analysis with dummy variables

\begin{tabular}{|l|l|l|}
\hline \multirow{2}{*}{ Tourism direction } & $\begin{array}{l}\text { Features of implementation of the tourism } \\
\text { direction }\end{array}$ & $\begin{array}{l}\text { Analytical interpretation in a } \\
\text { regression model }\end{array}$ \\
\hline \multirow{3}{*}{$\begin{array}{l}\text { Primary } \\
\text { tourism }\end{array}$} & Seaside vacation (a11) & $\mathrm{X} 1=1 ; \mathrm{X} 2=0$ \\
\cline { 2 - 3 } & Ecological vacation (a12) & $\mathrm{X} 1=0 ; \mathrm{X} 2=1$ \\
\cline { 2 - 3 } $\begin{array}{l}\text { Cultural and leisure } \\
\text { tourism }\end{array}$ & Wellness vacation (a13) & $\mathrm{X} 1=0 ; \mathrm{X} 2=0$ \\
\cline { 2 - 3 } & Crowd culture vacation (a21) & $\mathrm{X} 3=1 ; \mathrm{X} 4=0$ \\
\cline { 2 - 3 } & Historical and educational vacation (a22) & $\mathrm{X} 3=0 ; \mathrm{X} 4=1$ \\
\hline
\end{tabular}

The analytical feature of the marketing model takes the shape of a multiple regression model with dummy variables in accordance with the formula (1):

$$
\widehat{Y}_{t}=b_{0}+b_{1} X_{1}+b_{2} X_{2}+b_{3} X_{3}+b_{4} X_{4}+\varepsilon_{i}
$$

where: 
$\widehat{Y}_{t}$ - theoretical (predictive) value of the usefulness of the product with the corresponding forms of implementation of specific tourist destinations;

$b_{0}$ - constant of the regression model;

$b_{i}$ - i-th regression coefficient;

$X_{i}$ - i-th form of implementation of a tourist destination;

$\varepsilon_{i}$ - i-th residual characterizing the influence of random factors not taken into account in the regression model.

The measurement of the utility (attractiveness) as a dependent variable $\mathrm{Y}$ was made in accordance with the scale shown in Figure 3.

\begin{tabular}{|c|c|c|c|c|c|c|c|c|c|}
\hline $\mathbf{1}$ & $\mathbf{2}$ & $\mathbf{3}$ & $\mathbf{4}$ & $\mathbf{5}$ & $\mathbf{6}$ & $\mathbf{7}$ & $\mathbf{8}$ & $\mathbf{9}$ & $\mathbf{1 0}$ \\
\hline doesnotattract & \multicolumn{2}{|c|}{ ratherdoesnotattract } & \multicolumn{2}{|c|}{ somewhatattracts } & attracts & veryattractive \\
\hline
\end{tabular}

Fig. 3. Scale for assessing the attractiveness $Y$ of a territorial tourist product

In accordance with Table 1 and Formula 1, individual regression models were built for each respondent selected for participation in the field quantitative descriptive marketing research conducted by the authors, the plan of which is presented in Table 2 .

Table 2.Marketing research plan

\begin{tabular}{|l|l|}
\hline Marketing research plan & \multicolumn{1}{c|}{ Characteristic } \\
\hline Marketing research issue & Study of the preferences of potential tourists in the conduct of tourist recreation \\
\hline Research type & Final descriptive field marketing research \\
\hline Research method & PC-based survey using computer and Internet "CAWI" based on Google-forms \\
\hline Scaling tools & Metric detailed 10-point Jaster scale, metric interval scales, nominal scales \\
\hline Sampling outline & $\begin{array}{l}\text { List of subscribers of public communities in "Vkontakte" social network, } \\
\text { dedicated to tourism in the region }\end{array}$ \\
\hline Sampling method & Simple random sampling \\
\hline Population element & $\begin{array}{l}\text { A resident of the Kaliningrad region from 18 to 70 years old, interested in tourist } \\
\text { offers }\end{array}$ \\
\hline Sampling unit & $\begin{array}{l}\text { A subscriber of public communities in "Vkontakte" social network, dedicated to } \\
\text { tourism }\end{array}$ \\
\hline Coverage area & Kaliningrad region \\
\hline Period & $10.09 .2019-17.11 .2019$ \\
\hline Sample size & 1000 respondents \\
\hline
\end{tabular}

So, for each respondent, individual private utility $\mathrm{a}_{\mathrm{ij}}$ was calculated, on the basis of which the segmentation of the potential tourists was carried out using the methods of cluster analysis, the results of which are presented in Figure 4:

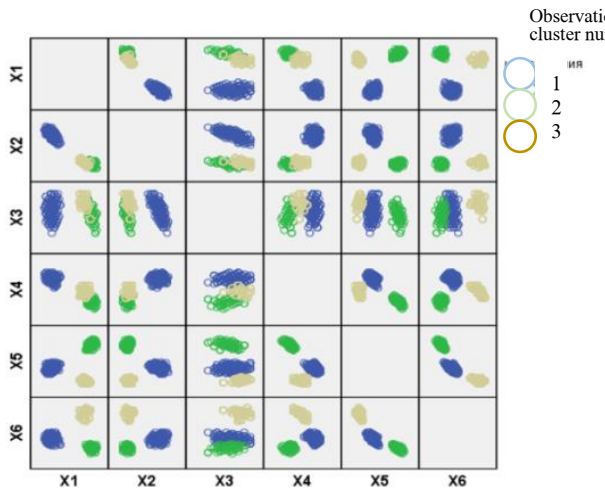

Matrix of scatter diagrams of clustered objects by the Kmeans method
Distance from observation to cluster center

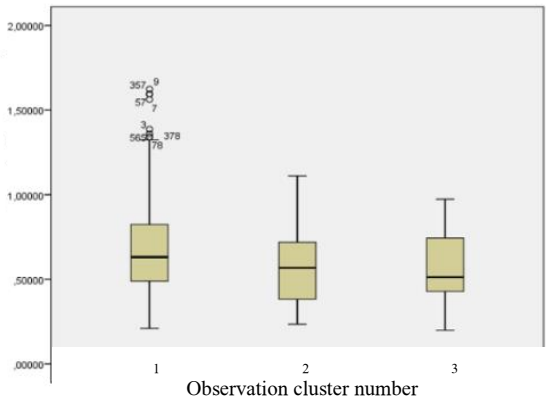

Scatter diagrams of intra-cluster distances of objects to the center of their clusters

Fig. 4. Market segmentation results using the iterative cluster analysis 
So, out of the three identified value segments of the tourists, in accordance with the decision of the administration and the chief specialist in the development of the territory of the municipality, the segment of ecological tourism and historical and educational recreation was chosen as the target, which is consistent with other studies on regional economics and tourism [9]. Within the framework of this segment, on the basis of the principal component method, such value attributes as "Impressions and pacification" and "Wellness and nature" were identified, which served as the basis for positioning the territorial product and developing a portfolio of investment projects for the development of the territory.

\section{Results and discussion}

Based on the results of the analysis, the concept of a territorial tourist product was created, which implements its agreed portfolio of the investment projects, consisting of 4 programs (Table 3), and a marketing complex for the territory "4P" (Table 4).

Table 3. Developed territorial tourist product of the Ladushkinsky urban district

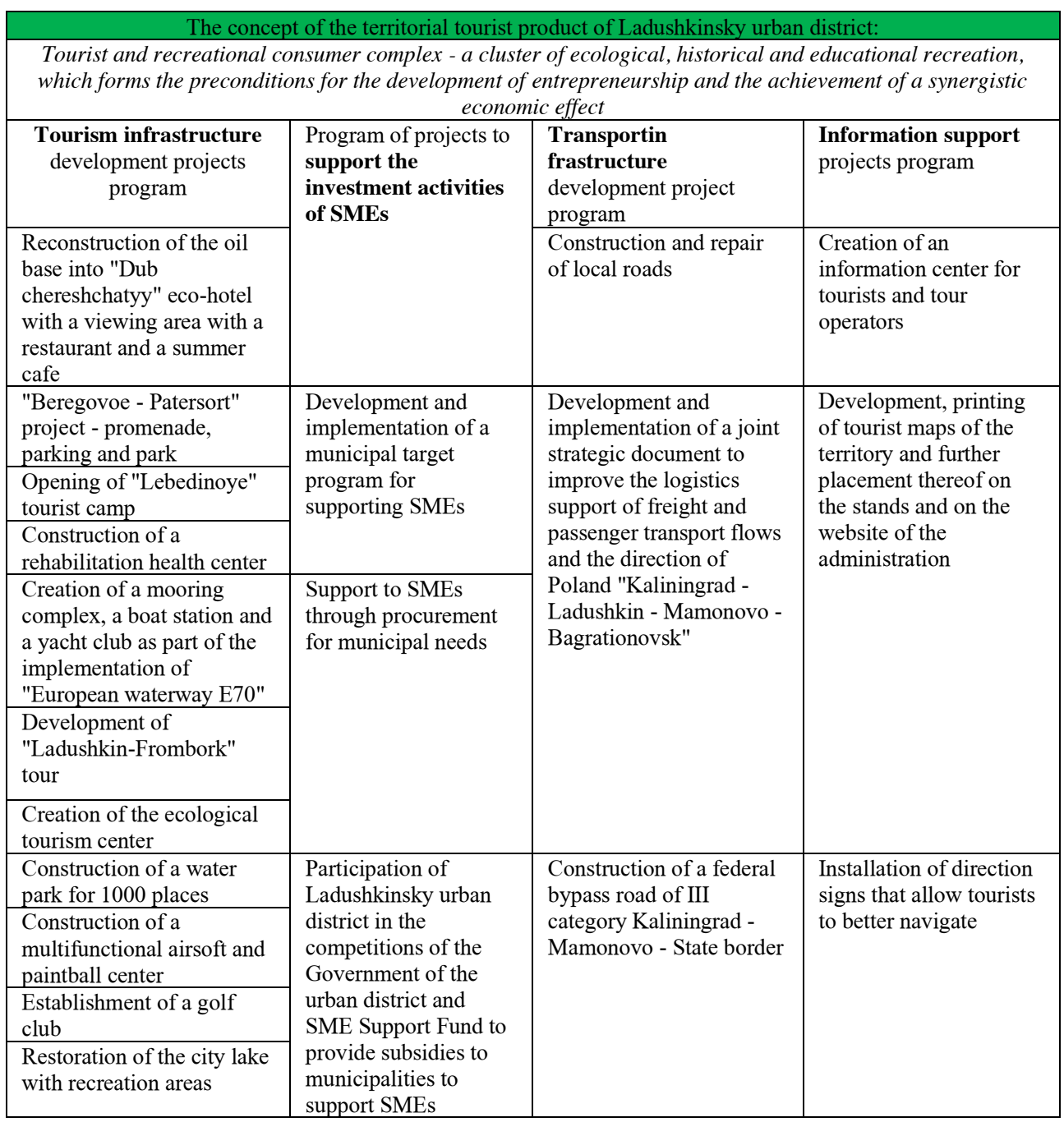


Table 4. Marketing complex "4P" of the tourist product of the Ladushkinsky urban district

\begin{tabular}{|c|c|c|}
\hline PRODUCT & & COST \\
\hline $\begin{array}{l}\text { Specialized recreation facilities: an eco- } \\
\text { hotel with a viewing area for the } 900 \text {-year- } \\
\text { old Petiolate Oak, a rehabilitation wellness } \\
\text { center near "Electron" tourist camp, } \\
\text { "Lebedinoye" tourist camp, "Beregovoe- } \\
\text { Patterort" promenade } \\
\text { Leisure sphere: water park for } 1000 \text { seats, } \\
\text { multifunctional airsoft and paintball club, } \\
\text { golf club, game center (quest rooms, } \\
\text { computer club, etc.), rope park, skating } \\
\text { rink } \\
\text { Historical and educational vacation: } \\
\text { "Ladushkin-Frombork" tour including a } \\
\text { visit of "Balga" castle, study of the } \\
\text { historical heritage of the 900-year-old } \\
\text { Petiolate Oak, a visit to the museums of } \\
\text { Mamonovo and followed by a yacht trip to } \\
\text { "Frombork" castle complex } \\
\text { Ecological vacation: cycling and hiking } \\
\text { on pre-designed eco-trails, collective } \\
\text { fishing based on the principles of } \\
\text { environmental sustainability, short hikes, } \\
\text { organizing picnics and camping, team } \\
\text { kayaking/canoeing, ecological tour with } \\
\text { wildlife sightseeing - 900-year-old } \\
\text { Petiolate Oak, lunch on the terrace of an } \\
\text { eco-hotel overlooking the oak, a visit to the } \\
\text { botanical garden and the regional center for } \\
\text { environmental education and tourism }\end{array}$ & $\begin{array}{c}\text { Model } \\
\text { "4P territories" }\end{array}$ & $\begin{array}{l}\text { For the investors: cost reduction - a } \\
\text { targeted program of support for SMEs, } \\
\text { which implies the provision of benefits and } \\
\text { subsidies in priority areas of financing, } \\
\text { participation of the municipal district in } \\
\text { tenders of the government of urban district } \\
\text { and SME Support Fund for providing } \\
\text { subsidies to municipalities to support SMEs, } \\
\text { and implementation of the municipal } \\
\text { procurement } \\
\text { For tourists: } \\
\S \text { an attractive price level of tours is lower } \\
\text { than ecological tours in Ozersk and the cost } \\
\text { of accommodation facilities is lower than } \\
\text { Zelenogradsk and Svetlogorsk levels } \\
\S \text { price incentives in the form of discounts to } \\
\text { attract "typical" representatives of the } \\
\text { ecotourism segment and historical and } \\
\text { educational recreation } \\
\S \text { price incentives for the integrated } \\
\text { consumption of the proposed tours in } \\
\text { conjunction with tourist infrastructure } \\
\text { facilities (for example, a discount on visiting } \\
\text { the water park when renting a room in an } \\
\text { eco-hotel and tourist camps for } 2 \text { persons or } \\
\text { more) }\end{array}$ \\
\hline $\begin{array}{c}\text { Tourist and recreational consumer cluster } \\
\text { complex, which forms the preconditions for } \\
\text { the development of entrepreneurship and } \\
\text { the achievement of a synergistic economic } \\
\text { effect }\end{array}$ & & $\begin{array}{c}\text { Favorable investment climate and conducive } \\
\text { pricing and promotion to the successful } \\
\text { entry of Ladushkinsky urban district into the } \\
\text { segment of ecotourism and historical and } \\
\text { educational recreation of the regional } \\
\text { tourist market } \\
\text { PROMOTION }\end{array}$ \\
\hline $\begin{array}{l}\text { Coastal and border area: implementation } \\
\text { of the international program for the } \\
\text { development of water tourism "European } \\
\text { waterway E-70 Rotterdam-Klaipeda" and } \\
\text { the construction of a mooring complex, a } \\
\text { boat station and a yacht club on the shores } \\
\text { of the Kaliningrad Bay to provide water } \\
\text { access to the territory for the foreign } \\
\text { tourists, the implementation of water tours } \\
\text { and development of the logistics system of } \\
\text { the territory } \\
\text { Transport and } \\
\text { construction and repair of local roads, } \\
\text { reconstruction and improvement of public } \\
\text { roads according to the standards of IV } \\
\text { technical category, improvement of park } \\
\text { zones, reconstruction of the city lake with } \\
\text { the creation of recreation areas, } \\
\text { implementation of the Safe City hardware } \\
\text { and software complex for environmental } \\
\text { monitoring in order to conservation of } \\
\text { recreational resources of the territory }\end{array}$ & & $\begin{array}{l}\text { Offline channels: BTL communications and } \\
\text { event marketing } \\
\text { Internet channels: } \\
\text { cooperation with regional bloggers on } \\
\text { Youtube, specializing in shooting vlogs of } \\
\text { recreation and everyday life, providing them } \\
\text { with personal discounts and attractive } \\
\text { conditions for visiting the tourist facilities } \\
\text { that will be presented to the potential } \\
\text { tourists in the form of blogger's vlog } \\
\text { feedback, banner advertising in public } \\
\text { tourist communities of Vkontakte social } \\
\text { network ing tourism } \\
\text { Information infrastructure: a the the } \\
\text { center that develops mass tourism events } \\
\text { within the framework of BTL } \\
\text { communications and Event marketing and } \\
\text { provides access to consolidated information } \\
\text { on current offers and promotions for } \\
\text { tourists, and providing tourist requests and } \\
\text { requirements for tour operators }\end{array}$ \\
\hline
\end{tabular}


According to the obtained expert estimates, the implementation of the proposed concept will increase the tourist flow from 0.1 to 150 thousand people per year, and the volume of tax revenues to the budget of the municipal unit - from 26.01 to 130 million rubles per year.

\section{Conclusion}

1. The author's methodology for developing the concept of the territorial tourist product within the framework of the marketing-analytical approach makes it possible to form a marketing multi-attribute model, taking into account the needs of the market and is aimed at the sustainable development of the territorial tourism activities.

2. The proposed methodology, in particular, the concept of the territorial tourist product and the coordinated portfolio of the investment projects that implements it, as well as the marketing interpretation of the proposed projects in the context of the tools of "4P" marketing complex, were tested on the example of "Ladushkinsky urban district" municipal unit.

3. The developed concept of the territorial tourist product and the proposed portfolio of the investment projects for its implementation were included in the investment "Strategy for the socio-economic development of " Ladushkinsky urban district" municipal unit for 2020-2030". The investment strategy, which includes the presented scientific research of the authors, won the regional Competition for the investment strategies for the development of the municipal units.

\section{References}

1. "On the Strategy of Economic Security of the Russian Federation for the Period up to 2030": Decree of the President of the Russian Federation of May 13, 2017 No. 208

2. K.O. Chertushkin, N.E. Golubev, Types of Donor and Recipient Regions, 264 (2017)

3. M.A. Churbakova, Cluster Approach to the Development of Infrastructure of Tourism and Recreational Areas, 359 (2019)

4. D.T. Akhobadze, Organizational and Economic Mechanisms for Implementing Strategic Priorities for Tourism and Recreation in North-West Russia, 109 (2017)

5. A.P. Gapanovich, Recreational zoning of the Kaliningrad Region, 152 (2014)

6. Frolova, E.V., Kabanova, E.E., Tourist Attraction Development Factors of Russia's Municipalities, 115 (2017)

7. S.A. Sevastyanova, Regional planning of tourism and hotel management: study guide, 174 (2007)

8. R. H. Tsiotsou, Introduction to Strategic Marketing in Tourism, 35 (2012)

9. E.P. Afanasyeva, Features of tourism development in the coastal zones of the Kaliningrad region, 69 (2014) 